\title{
The InAugural MeEting of The OCEANOGRAPHy SocIETy
}

\author{
By Stan Wilson, Dave Brooks, Rana Fine, and Chris Mooers
}

$T_{H}$ HE Oceanography Society announces its inaugural meeting, to be held at the Monterey Convention Center and the adjacent Doubletree Hotel, Monterey, California, on August 27-30, 1989. The program will be uniquely unifying for oceanography, and it will highlight the diversity of the field as well. It will be multi-disciplinary, with three days organized around a central theme of importance to the future of oceanography.

Each of these days will feature invited speakers in a plenary session and contributed papers in a poster session. This format was chosen to complement, not compete with, other meetings available to oceanographers.

The posters will be co-located with the exhibits and refreshments, as well as conveniently arranged to promote dialogue. It is anticipated that the exhibits program, displaying the latest oceanographic services and products, will be substantial and enrich the overall meeting. In addition, two special seminars on Technology Advances will be given. An active schedule of social events is planned, and the Society will install its first slate of elected officers at a business meeting.

A variety of meeting rooms adjacent to the exhibit area will be available for scheduling by research and topical groups. The latest details of the meeting program will be posted on the Omnet/Telemail bulletin board OCEANS. The final program and an abstract volume will be available at the meeting. You are cordially invited to attend the meeting and participate in the gala inaugural festivities of The Oceanography Society.

\section{Call for Poster Abstracts.}

Contributed poster abstracts should be directed to the Meeting Coordinator, E.H. Pechan and Associates, Inc. Abstracts and billing information may be submitted by electronic mail, the preferred method, by following the instructions noted below. Otherwise, call Pechan at their conference hotline number (703-941-4490) and request information on abstract format and submission procedure. Then mail completed abstracts to: E.H. Pechan and Associates, Inc., Attention: TOS Inaugural Meeting, 5537 Hempstead Way, Springfield, VA 22151.

Abstracts are limited to 300 words each, including title and author information. To submit an abstract electronically, prepare and store the text offline, then log-on to Omnet/Telemail, and at the command prompt enter COMPOSE TOS.MEETING.ABS for interactive instructions that will provide information on abstract format and guide you through the complete submission procedure. An individual may be the sole or first author on only one poster. The abstract fee is $\$ 25$, which covers processing and publication, if accepted, in the abstract volume. Be prepared to give a major credit card number (AX, MC, or VISA), or indicate subsequent payment by check or money order. Abstract titles and content should be appropriate to one of the broad session themes.

All submitted abstracts will be forwarded to the appropriate session chairman and the program chairperson, who will determine which posters will be accepted for presentation at the meeting. Space is limited to 100 posters in each session. There is the possibility that a limited number of IBM PCs may be available for poster presentations; if interested in exploring this option, call Ms. Annette Najjar at Pechan, Inc. Submitted abstracts must be received by Pechan by May 1, 1989. Authors will be notified of abstract acceptance status by May 22 . Accepted abstracts may be updated as late as August 1, prior to printing of the abstract volume.

\section{Call for Exhibits.}

Exhibit booths will be available in the Exhibit Hall, immediately adjacent to the poster displays and the refreshment center. The rental fee for a standard $10^{\prime} \times 10^{\prime}$ exhibition booth is $\$ 1,000$. In addition, each exhibitor must pay a registration fee of $\$ 130$, which includes registration benefits as noted below. To reserve space, and for additional information, please contact Pechan. Exhibit space is limited and will be reserved in order of requests.

\section{Registration.}

To register for the meeting, fill out a copy of the registration form (p. 42) and mail it with appropriate payment to Pechan. Alternatively, log-on to Omnet/Telemail, and at the command prompt enter COMPOSE TOS.MEETING.REG for interactive instructions. You will be asked to supply the information requested on the registration form and a major credit card number for payment of the registration fee. You will receive confirmation of registration and subsequent meeting details from Pechan. The deadline for advance registration is August 4. Full refunds will be provided if written notice of cancellation is received by Pechan before August 11 .

The registration fee covers attendance at all scientific and social functions, including three continental breakfasts at the Doubletree Hotel, coffee and soft-drink breaks in the poster and exhibit area, the business meeting, no-host receptions Sunday evening at the Doubletree Hotel and Tuesday evening at the Pacific House, and the dinner reception Monday evening at the Monterey Bay Aquarium. Each registrant will receive a final Meeting Program and Abstract Volume at the meeting. As an option, spouses may register for all social events or just the aquarium function. Please note that the conference center auditorium is limited to 500 seats, for which the first 


\section{PoCKeT PROGRAM}

Sunday, August 27

Evening (Doubletree Hotel and Exhibit Hall)

No-host reception and icebreaker

Exhibit Program begins

Monday, August 28

Theme One: "What determines thermohaline and chemical stratification of the ocean?"

Chairman, Amold Gordon, Lamont-Doherty Geological Observatory

Morning (Conference Center)

Opening Remarks: David Packard

Plenary Session with Invited Speakers:

Ann Gargett, Institute of Ocean Sciences,

Patricia Bay; James Price, Woods Hole Oceanographic Institution;

Arnold Gordon; Edward Boyle, Massachusetts Institute of Technology; and Richard Jahnke, Skidaway Institute of Oceanography

Afternoon (Conference Center and Exhibit Hall)

Technology Advances: "Trends in graphics and visualization in oceanography," James O'Brien, The Florida State University

Contributed posters with sub-themes: vertical mixing, deep-water formation, thermocline ventilation, temporal changes, particulates, nutrients and oxygen, marginal exchanges, and paleo-oceans

Evening (Monterey Bay Aquarium)

Complimentary buffet dinner, reception, and aquarium highlights

Tuesday, August 29

Theme two: "What limits productivity in the oceans?"

Chairman, Trevor Platt, Bedford Institute of Oceanography

Morning (Conference Center)

Plenary Session with Invited Speakers: Shubha Sathyendranath, Dalhousie University; Donald Olson, University of Miami; Christopher Langdon, Lamont-Doherty Geological Observatory; François Morel, Massachusetts Institute of Technology; and Hugh Ducklow, Horn Point Environmental Laboratories

Afternoon (Conference Center and Exhibit Hall)

Contributed posters with sub-themes: physical controls, optical controls, nutrient regulation, trace metals, export from the photic zone, heterotrophy, respiration, food web analysis, and paleo-production.

Business Meeting and Installation of Officers

Keynote Address: "Why We Are Oceanographers," Henry Stommel, Woods Hole Oceanographic Institution

Exhibit Program ends

Evening (Pacific House Courtyard)

Inaugural Reception with Mariachi Band; cash bar

Wednesday, August 30

Theme Three: "What is the prognosis for observing and describing the ocean?"

Chairman, Melboume Briscoe, Office of Naval Research

Morning (Conference Center and Exhibit Hall)

Technology Advances: "Biotechnology in the ocean sciences," Richard Cassin, Ocean Sciences Research Institute

Contributed posters with sub-themes: global ocean climate, ocean monitoring, coastal oceans, air-sea fluxes, oceanic mixing, real-time productivity, chemical fluxes, ridge-crest processes, and new technology.

Afternoon (Conference Center)

Plenary Session with Invited Speakers: John Delaney, University of Washington; Kenneth Brink, Woods Hole Oceanographic Institution; Marlon Lewis, NASA Headquarters; and Ants Leetmaa, Climate Analysis Center, NOAA/NWS.

Closing Remarks: Walter Munk, Scripps Institution of Oceanography

500 registrants will have priority. Additional registrants will be able to view the plenary sessions on a large-screen closedcircuit TV in an adjacent area.

Hotel Accommodations.

The headquarters hotel for the meeting is the Doubletree Hotel (408-649-4511), adjacent to the Monterey Conference Center. A block of rooms has been reserved until July 27 at the special meeting rate of $\$ 85 / \$ 95$ (single/double) per day for the first 150 rooms and $\$ 95 / \$ 105$ (single/double) per day for the next 150 rooms. For information on overflow accommodations, check the appropriate box on the registration form. Please note that reservations are to be made by the attendee. Early reservations are strongly advised.

\section{Travel Arrangements.}

The Monterey Airport has connecting service with San Francisco (SFO), San Jose (SJC), and Los Angeles (LAX). Information on discount airfares will be provided on the OCEANS bulletin board. Driving time to Monterey from the San Jose and San Francisco airports is about 2 and 2.5 hours, respectively. Scenic but longer alternatives include coastal and mountain routes. Students or others wishing to make special arrangements to share costs are encouraged to coordinate needs by using the Omnet/ Telemail box GRAD.STUDENTS. Partial support for oceanographers from developing countries is available from SCOR; application must be received at TOS headquarters by June 1 .

\section{Cosponsoring Societies.}

The cosponsoring societies are the American Meteorological Society (AMS), Canadian Meterorological and Oceanographic Society (CMOS), Challenger Society for Marine Science (CSMS), IEEE Oceanic Engineering Society (IEEE/OES), International Association for the Physical 


\section{REGISTRATION \\ FOR THE INAUGURAL MEETING OF THE OCEANOGRAPHY SOCIETY}

August 27-30, 1989

Name (to appear on badge)

Institution (to appear on badge)

Address

City/State/Zip/Country

Area Code/Phone Number

Electronic Mail Address

Days attending $\square$ Sunday $\square$ Monday $\sqsupset$ Tuesday $\square$ Wednesday

I am a member of The Oceanography Society $\square$ Yes $\quad \sqsupset$ No

I am a member of the following cosponsoring society and wish to register at TOS member rate:

\section{$\square$ AMS $\square$ CMOS $\square$ CSMS $\square$ IEEE/OES $\square$ IAPSO $\square$ MTS $\square$ SCOR}

ADVANCE REGISTRATION FEES (Must be received by Pechan by August 4) Full Meeting

$\sqsupset$ TOS member $\$ 130$

$\square$ TOS student member $\$ 65$

$\sqsupset$ Non-member $\$ 180^{*}$

$\square$ Non-member student $\$ 75^{*}$

*Includes TOS membership if application filed before September 1, 1989.

One Day Only (excludes aquarium buffet/reception)

$\square$ TOS member $\$ 65$

$\square$ TOS student member $\$ 32.50$

Non-member $\$ 90$

$\square$ Non-member student $\$ 37.50$

$\square$ Aquarium buffet/reception $\$ 40$

Spouse (Name to appear on badge)

$\square$ All functions except scientific sessions $\$ 70 \square$ Only aquarium buffet/reception $\$ 40$

Additional fee for registration after August 4.

$\sqsupset$ Members and Non-members $\$ 20$

Students $\$ 10$

Total registration fee (sum boxes checked) $\$$

My check payable to the The Oceanography Society is enclosed or

Charge my credit card as follows:

AmEx

Card number

Visa

$\square$ MasterCard

Expiration date

Signature

Please send information on overflow accommodations.

Mail this form to: Pechan and Associates, Inc., Attention: TOS Inaugural Meeting, 5537

Hempstead Way, Springfield, VA 22151. Alternatively, have the information on this form available, log-on to Omnet/Telemail, and at the command prompt enter COMPOSE TOS.MEETING.REG for interactive instructions.
Sciences of the Ocean (IAPSO), Marine Technology Society (MTS), and Scientific Committee on Oceanic Research (SCOR). Organization.

The Program Chairperson for this meeting is Rana Fine. The TOS Meetings Committee has the following members: Stan Wilson (co-chair), Chris Mooers (co-chair), Richard Cassin, John Cullen, David Brooks, Rana Fine, and Bob Spindel. The Local Organizing Committee includes Curtis Collins, Naval Postgraduate School (chair); Richard Barber, Monterey Bay Aquarium Research Institute; John Martin, Moss Landing Marine Laboratory; and Dennis Powers, Hopkins Marine Station.

We would like to recognize the Monterey Bay Aquarium for its gracious support of the Inaugural Meeting of The Oceanography Society.

Should you have any additional questions, contact TOS headquarters at 1755 Massachusetts Avenue, NW, Suite 700, Washington, DC (202-232-3900 or OCEANOGRAPHY.SOCIETY/OMNET). $\square$

\section{Smooth Sailing, LetTy!}

$\mathrm{T}_{\mathrm{H}}$ HE first two issues of Oceanography Magazine were published with the help of Leticia Benning, whose name appeared on the masthead under the title Administrative Assistant.

Letty expertly guided us through the awkward early steps in establishing the various accounts and procedures needed to organize and publish the first editions of the magazine. Her experience and training in management and accounting helped us avoid some of the impending pitfalls. It is now painfully obvious just how naïve we all were (and still are, to a considerable extent) when we decided to publish a magazine, with only a vague idea of what was involved in such a venture.

We just jumped in, hoping to learn how to swim. We are still thrashing about a bit, but with somewhat less desperation and prospects of at least a serviceable backstroke. Letty helped us through the early stages of "creaks and groans," which I promised would surface. and she got us on the road to sensible organization, a skill at which I am notoriously deficient.

Letty has recently moved on to another job, one that will allow her to further develop and apply her considerable talents within Texas A\&M University. We at the magazine wish her, in the finest marine tradition, smooth sailing. J—Dave Brooks 